\title{
Male Opponents and Supporters of Woman Suffrage: Iowa in 1916
}

\author{
Thomas G. RYaN
}

$\mathbf{E}_{\text {MPHASIS on }}$ the long history of the woman suffrage movement in the United States as essentially a battle of the sexes, with women favoring and men opposing the extension of the franchise, obscures the extent to which the struggle was actually a contest between men who favored and men who opposed woman suffrage. In states where men monopolized the suffrage, legislative and electoral battles pitted men against other men. Even though women led the campaign for suffrage, men cast the ballots which decided the question. Insofar as the struggle for woman suffrage included a contest between pro- and antisuffrage men, analysis of male voting behavior in statewide referenda can help illuminate several aspects of American political and social history. The first is the suffrage movement itself, which will remain only partially explored so long as we continue to interpret it primarily in female-versus-male terms.

The second is the attitude of both men and women, from various social groups, on the question of woman suffrage. Insofar as men and women with similar backgrounds shared common beliefs and values, exploration of male voting behavior in suffrage referenda may shed light on the aggregate attitudes of various social groups. While analyses of the women who were vis- 
ible supporters, or opponents, of suffrage extension may help answer questions about the backgrounds of women active in the movement, this approach permits study of only a female elite. ${ }^{1}$ Analysis of mass male voting behavior, on the other hand, offers the possibility of discovering the attributes of large numbers of women, as well as of men, who were associated with either side of the question.

A third area which studies of this type could illuminate is Progressive era political history. Analyses of referenda voting behavior could include investigations of the role of ethnicity, particularly attempts to determine if such variables as nationality and religion were as closely related to voting behavior in suffrage referenda as recent studies of late nineteenth-century voting have concluded they were in partisan elections.

Public opinion on specific questions is the fourth and final area where referenda studies could further our understanding. Special elections in which voters are asked to approve or reject specific proposals offer unique opportunities to determine the views of various groups regarding a particular issue. Once group voting behavior is known, the historian has a foundation from which to consider questions of voter motivation. The nature of general elections complicates attempts to determine voter perception of specific issues. The large number of woman suffrage referenda in the decades preceding the enactment of the Nineteenth Amendment permits students of pre-1930s voting behavior to compensate for the absence of survey research on specific public policy questions. Analysis of voting behavior in individual referenda permits the student of early twentiethcentury America to study the views of the widest possible public on issues of the era.

On June 5, 1916, Iowa men rejected a proposed woman suffrage amendment to the state constitution. Both the statewide vote and the county vote totals indicate that Iowa men were quite evenly divided on the question. Just under half (48.5 per-

${ }^{1} \mathrm{~A}$ recent example of such an elite study is the analysis of "eighty-nine women whose primary claim to being notable was their suffrage activity," by Anne F. Scott and Andrew M. Scott, One Half the People: The Fight for Woman Suffrage (Philadelphia: J. B. Lippincott Co., 1975), pp. 164-165. 
cent) of the voters marked their ballots for the amendment; almost exactly the same proportion of Iowa counties (fortyeight of ninety-nine) returned majorities for woman suffrage. The statewide figures, however, obscure the wide variations which occurred in the vote from county to county. The vote was close in only a little more than one-third (thirty-eight) of the state's counties. In thirty counties, the pro-suffrage forces won easily, amassing over 55 percent of the vote. In thirty-one other counties, the opponents of woman suffrage won handily, as they captured more than 55 percent of the vote. The widest variations occurred between Dubuque and Page counties. Only about one-fourth (27.6 percent) of the voters in Dubuque County marked their ballots for woman suffrage, while almost two-thirds (65.9 percent) of Page County voters registered their approval of the proposal. ${ }^{2}$

The wide variations in the county-by-county vote suggest a number of questions regarding this phenomenon. What groups of men voted for woman suffrage, and what groups opposed the proposal? What relationship, if any, existed between voting behavior in the referendum and such variables as nationality, religion, nativity, political affiliation, and community size? Was the link between woman suffrage and prohibition as strong as many writers have suggested ${ }^{3}$ Were rank-and-file GermanAmerican voters as opposed to woman suffrage as German-

${ }^{2}$ Iowa Official Register, 1917-1918 (Des Moines, 1917), pp. 462-481. For an indication that variations in the degree of support for woman suffrage varied even more from township to township than they did from county to county, see pp. 545-546.

${ }^{3}$ Among those who suggest that woman suffrage and prohibition were closely linked are Ross Evans Paulson, Women's Suffrage and Prohibition: $A$ Comparative Study of Equality and Social Control (Glenview: Scott Foresman \& Co., 1973); Frederick Luebke, Bonds of Loyalty: GermanAmericans and World War I (De Kalb: Northern Illinois University Press, 1974); Alan P. Grimes, The Puritan Ethic and Woman Suffrage (New York: Oxford University Press, 1967); Carl Wittke, The German-Language Press in America (Lexington: University of Kentucky Press, 1957); Ida Husted Harper, ed., The History of Woman Suffrage, 6 vols. (New York: National American Woman Suffrage Assn., 1922), vol. 6; and Gerd Korman, "Political Loyalties, Immigrant Traditions, and Reform: The Wisconsin German-American Press and Progressivism, 1909-1912," Wisconsin Magazine of History 40 (Spring 1957). 
American organizations and the German-language press $?^{4}$ Were other immigrant groups opposed to woman suffrage? ${ }^{5}$

Analysis of the vote at the county level indicates that four types of counties, and four groups of Iowans, supported woman suffrage at considerably higher levels than other counties, and other voters, in the state. Dry counties, BritishAmerican counties, Protestant counties, and Republican counties returned the largest majorities for woman suffrage. Conversely, the proposal fared least well in wet counties, counties with the largest proportions of residents from continental Europe (especially from Germany), Roman Catholic counties, and Democratic counties. Community size, on the other hand, bore almost no relationship to voting behavior, as both rural and urban Iowans supported woman suffrage at approximately the same levels.

Iowa supporters of prohibition gave the most support to woman suffrage. As indicated in Table 1, the Pearson productmoment correlation between the vote in the 1916 woman suffrage referendum and a 1917 referendum on a proposed prohibition amendment to the state constitution was .72 , considerably stronger than the next highest correlation, $-.56 .^{6}$ The .72 correlation between the two referenda votes indicates that 51.8 percent of the vote on woman suffrage can be statistically explained by the views of Iowans on the question of prohibition. The close relationship between the two referenda votes offers

${ }^{4}$ For an indication that the German-language press and such organizations as the German-American Alliance opposed woman suffrage, see Wittke, German Language, pp. 162, 201, 217; Korman, "Political Loyalties," pp. 162-168; and Frederick Luebke, "The German-American Alliance in Nebraska, 1910-1917," Nebraska History 49 (Summer 1968): 179.

${ }^{5}$ Harper, History Woman, 6: 591, describes the defeat of a 1916 woman suffrage referendum in South Dakota as " . . . the same old story, principally the foreigners, especially the Germans, had once more denied to American women the privilege which they, themselves, had acquired so easily." While Harper attempts to explain the results of unsuccessful suffrage referenda in a number of states, she appears to have sought villains rather than understanding. The statement above is her entire explanation of the results of the South Dakota vote.

'When the text refers to data listed in tables no additional citations to those sources will be given. 


\section{Woman Suffrage}

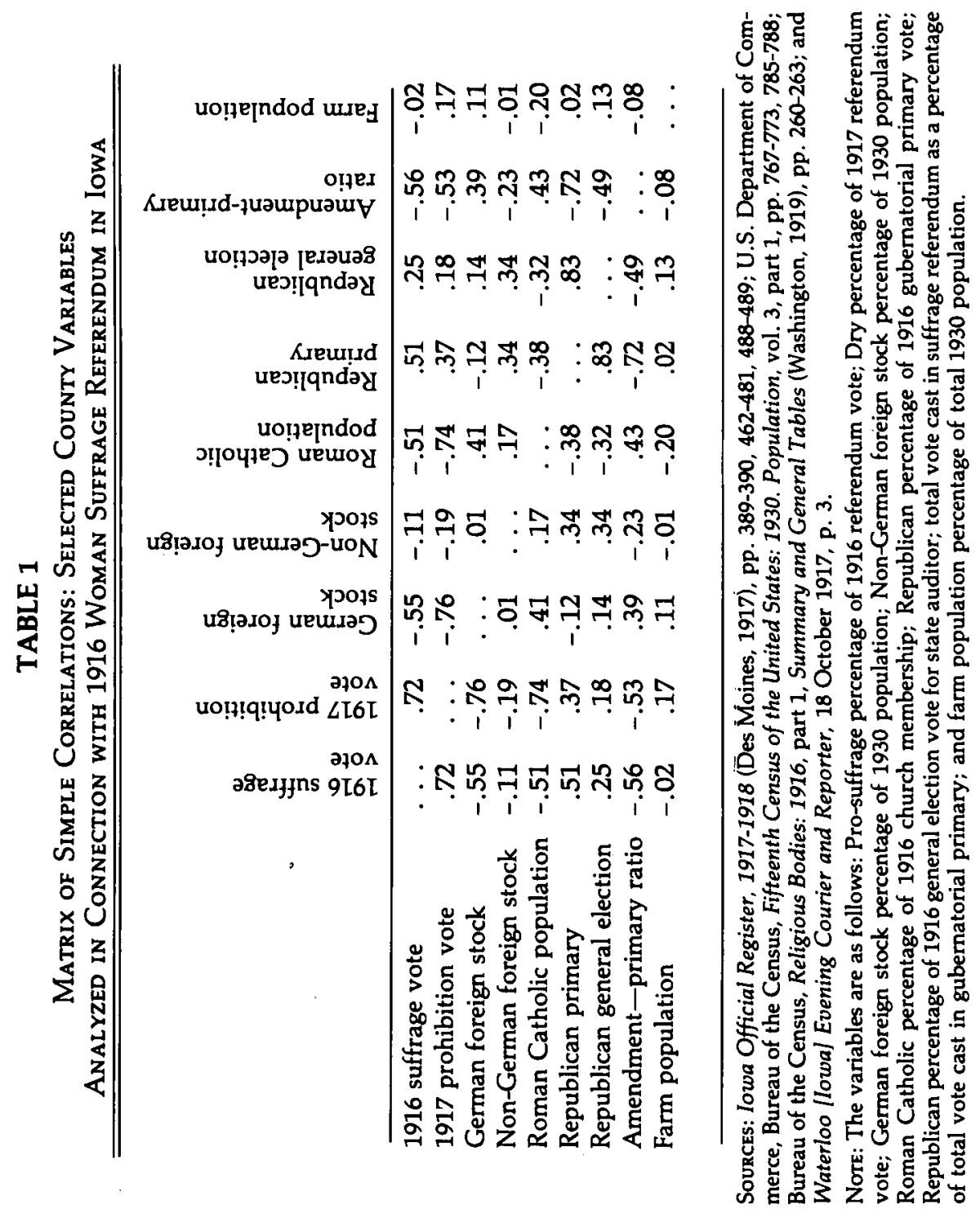


considerable evidence that among grass-roots voters support for woman suffrage usually went hand-in-hand with support for prohibition. A similar relationship existed among rank-andfile voters on the other side of the fence, as those who opposed prohibition also opposed woman suffrage. While motivation is often difficult to determine, the strong association between the 1916 and the 1917 referenda votes tends to support the testimony of various individuals who contend that drys indeed favored woman suffrage, and wets opposed the proposal, because both groups believed that enfranchising women would increase the proportion of the electorate in favor of prohibition.

Although no other variable corresponds with the vote on woman suffrage as closely as the 1917 prohibition vote, the statistical relationships between the suffrage vote and several other factors were high enough to indicate that nationality, religion, and political party affiliation were each associated with 1916 voting behavior. Among national groups, German-Americans demonstrated the greatest opposition to woman suffrage. The correlation between the first- and second-generation GermanAmerican population and the 1916 vote in Iowa counties was -.55. This indicates that the size of the German foreign stock in Iowa counties can explain 30.3 percent of the vote in the 1916 referendum. While half of all Iowa counties returned majorities for woman suffrage, only about one-seventh (three of twenty) of the most German counties in the state approved the proposal. ${ }^{7}$ The mean pro-suffrage vote in the twenty German counties was 40.7 percent, compared with a statewide mean of $\mathbf{4 8 . 5}$ percent, and a mean of 51.2 percent in the seventy-nine least German counties.

Although accounts of the woman suffrage movement which attempt to explain the defeat of suffrage referenda in various states often attribute defeat to the opposition of the foreignborn, in the 1916 Iowa referendum no other non-Englishspeaking foreign stock group in the state equaled German-

"In each of the twenty "most German" counties in the state, first- and second-generation German-Americans were at least twenty percent of the total population. The counties were: Bremer, Butler, Carroll, Cedar, Chickasaw, Clayton, Clinton, Crawford, Dubuque, Franklin, Grundy, Hardin, Ida, Jackson, Kossuth, Lyon, O'Brien, Osceola, Plymouth, and Scott. 


\section{Woman Suffrage}

Americans in rejecting the proposal. Other national groups from continental Europe recorded levels of support for woman suffrage between those of British-Americans, who registered the most support, and German-Americans, who registered the least. This is evident in both a county-level analysis of the voting behavior of all non-German foreign stock groups combined, and in the precinct (township) voting record of specific national groups.

While the correlation of the first- and second-generation German-American population with the 1916 vote was -.55 , that of all other foreign stock groups combined was only -.11. ${ }^{8}$ Thus, the size of the non-German foreign stock population in Iowa can explain only 1.2 percent of the 1916 vote, while the size of the first- and second-generation German population can explain 30.3 percent, more than twenty-five times as much.

A study of the vote in ethnic townships throughout the state suggests three conclusions. First, no non-English ethnic group gave a majority to the suffrage cause. Second, no other foreign stock group opposed woman suffrage as decisively as the German-Americans. Third, and last, among the non-German ethnic groups, the degree of support for woman suffrage varied considerably. As Table 2 indicates, voters in Swedish townships supported suffrage extension at slightly more than twice the level of voters in Czech townships, and at more than two and one-half times the level in German townships.

TABLE 2

Mean 1916 Pro-Suffrage Vote in Iowa Ethnic Townships

\begin{tabular}{lll}
\hline \hline British & $51.1 \%$ & $(\mathrm{~N}=22)$ \\
Swedish & $49.0 \%$ & $(\mathrm{~N}=24)$ \\
Danish & $47.9 \%$ & $(\mathrm{~N}=16)$ \\
Norwegian & $36.5 \%$ & $(\mathrm{~N}=22)$ \\
Irish & $34.4 \%$ & $(\mathrm{~N}=17)$ \\
Dutch & $25.8 \%$ & $(\mathrm{~N}=14)$ \\
Czechoslovakian & $24.3 \%$ & $(\mathrm{~N}=17)$ \\
German & $18.7 \%$ & $(\mathrm{~N}=36)$ \\
\hline
\end{tabular}

Sources: Census of lowa, 1885 (Des Moines, 1885), pp. 1-163; Official Register, pp. 462-481.

${ }^{8}$ The composition of the non-German foreign stock population was quite 
The wide variations in the pro-suffrage vote among various ethnic groups in Iowa suggests that explanations of voting behavior in suffrage referenda by referring to the "immigrant" vote should be made carefully. At a minimum, analyses of "immigrant" referenda voting behavior should include separate examinations of each ethnic group. Although the lowa data appear to support the conclusion that immigrants usually contributed to the defeat of suffrage referenda, they also indicate that no two ethnic groups voted alike, and that the members of some non-English groups cast almost as many votes for suffrage extension as against it. While men in Iowa's most German townships rejected woman suffrage more than four to one almost half of those in Swedish and Danish townships voted for the proposal. Moreover, both Swedish and Danish townships recorded pro-suffrage votes only slightly below those of British townships.

A second ethnic factor, religion, was also closely associated with 1916 voting behavior in lowa. The correlation between the Roman Catholic percentage of all church members in lowa counties and the 1916 vote was -.51, only slightly below the - .55 correlation of the German foreign stock with the 1916 vote. While most Iowa Catholics were of German ancestry, Table 2 suggests that the two other chief Catholic national groups in the state, Irish-Americans and Czech-Americans, also gave little support to woman suffrage. The mean pro-suffrage vote in Irish and Czech townships was below that of every Protestant national group except the Dutch. ${ }^{9}$ In fact, the data suggest that religion was even more closely related to 1916 voting behavior than was nationality. While the usual close relationship between nationality and religion makes this proposition difficult to test, the division of German-Americans

varied, as indicated in the following listing of the proportion of the total nonGerman foreign stock population accounted for by each of the seven largest non-German groups: Swedes-12.4 percent, Norwegians-12.3 percent, English-10.6 percent, Danes-10.3 percent, Irish-10.2 percent, Dutch-7.8 percent, and Czechs-6.7 percent.

${ }^{9}$ Virtually all Dutch in Iowa were Protestant, chiefly Reformed. 
between Catholicism and Protestantism permits an examination of the hypothesis.

Although virtually every German county in the state registered low levels of support for woman suffrage, German Catholic counties recorded a pro-suffrage vote significantly lower than that in German Protestant counties. ${ }^{10}$ In the eight German Catholic counties, slightly more than one voter in three (35.4 percent) marked his ballot for woman suffrage, compared with nearly one voter in two (46.5 percent) in the eight German Protestant counties. While none of the German Catholic counties turned in a majority for woman suffrage, three of the eight German Protestant counties did. Moreover, none of the individual pro-suffrage percentages of the eight German Catholic counties matched the mean suffrage vote ( 46.5 percent) of the German Protestant counties. On the other hand, all but one of the eight Protestant counties exceeded the mean of German Catholic counties. ${ }^{11}$

Carroll, one of the eight German Catholic counties, supplies an excellent example of the wide variation in the degree of support for the woman suffrage proposal between two types of townships in the same county. In Roselle, where most residents were German Catholic, only 3.7 percent voted for woman suffrage. In nearby Glidden, where very few persons were either

10 "German" counties were those in which first- and second-generation Germans were at least twenty percent of the total population; "Catholic" counties those in which at least forty percent of all church members were Roman Catholics; and "Protestant" counties those in which Roman Catholics were less than twenty percent of all church members. The German Catholic counties were Carroll, Chickasaw, Clinton, Dubuque, Jackson, Kossuth, Plymouth, and Scott. The German Protestant counties were Bremer, Butler, Cedar, Franklin, Grundy, Hardin, Ida, and O'Brien.

${ }^{11}$ In four other German counties, where Catholics were from 20.0-39.9 percent of all church members, the mean pro-suffrage vote was 39.5 percent. This was above the 35.4 percent mean in German Catholic counties but below the 46.5 percent in German Protestant counties. The lower pro-suffrage vote in German Catholic than in German Protestant counties is especially striking in view of the larger proportions of first- and second-generation Germans in the latter: 23.1 percent compared to 26.3 percent. This is a further indication that, at least in Iowa, opposition to woman suffrage was even more closely associated with Roman Catholicism than with German ancestry. 
German or Catholic, 86.4 percent voted to extend the franchise to women. ${ }^{12}$

Further indication of the close association between Catholicism and opposition to woman suffrage is apparent in the voting behavior of Iowa Catholic counties with few GermanAmericans. In the four Catholic counties where first- and second-generation Germans were less than ten percent of the population, the mean pro-suffrage vote was 41.2 percent. ${ }^{13}$ This was about midway between the pro-suffrage vote ( 35.4 percent) recorded in German Catholic counties and that (46.5 percent) in German Protestant counties. In other words, Iowa Catholic counties with few residents of German ancestry registered less support for suffrage extension than German Protestant counties in the state. This indicates that religion, at least Catholicism, was even more closely related to voting behavior in the suffrage referendum than was German ancestry.

\section{$\mathbf{R}$} RePliCan counties joined Protestant, British-American, and dry counties in casting a majority of their votes for woman suffrage. This was, of course, consistent with the traditionally larger proportions of Protestants and drys in the Republican rather than in the Democratic party. Balloting on the woman suffrage proposal was held in conjunction with the 1916 primary election. Thus, it is possible to compare referendum voting behavior with partisan voting behavior on the same day, as well as with partisan voting behavior in the November general election. The correlation coefficient between the 1916 Republican share of the total gubernatorial primary vote and the 1916 pro-suffrage vote was quite high, .51, while that between the pro-suffrage vote and the Republican share of the total November vote for state auditor was considerably smaller,

${ }^{12}$ Official Register, p. 464; Census of lowa, 1885 (Des Moines, 1885), p. 12; Official Catholic Directory 1966 (New York, 1966), pp. 770-772; Iowa General Highway and Transportation Maps (Des Moines, 1974), p. 14.

${ }^{13}$ Catholics were at least forty percent of all church members in both German and non-German "Catholic" counties. The non-German Catholic counties were Johnson, Palo Alto, Winneshiek, and Woodbury. 
.25. Thus, the Republican gubernatorial primary vote can statistically explain 26.0 percent of the suffrage vote, while the November vote for the Republican candidate for state auditor can account for only 6.3 percent of the suffrage vote. The considerably higher correlation of the June, than of the November, Republican vote with the suffrage vote was chiefly a result of vigorous statewide contests for several GOP nominations in 1916, unlike the situation in the Democratic party, which had no primary contests for state offices. ${ }^{14}$ Thus, Republicans constituted a considerably larger proportion of the June than of the November electorate.

While the absence of primary contests may have kept many Democrats from casting party ballots in the June 5 election, it does not appear to have persuaded them to avoid the voting booths entirely on that date. A total of 30,689 more Iowa men cast ballots in the suffrage referendum than in the gubernatorial voting on the same day, as just over 110 Iowans voted in the referendum for every 100 who voted for a gubernatorial candidate. ${ }^{15}$ Indications are that most of those who voted on the suffrage question but not in the gubernatorial primary were Democrats.

Although earlier writers interpret the larger number of ballots cast in the referendum than in the gubernatorial primary as evidence of fraud on the part of the anti-suffrage forces, ${ }^{16}$ the circumstances of the primary election and the relationships among several variables, e.g., the size of the referendum vote, the direction of that vote, and the size of the Democratic and of the Republican gubernatorial primary votes, suggest three interrelated, alternative conclusions. First, the absence of contests in the Democratic primary produced a relatively low turnout in the party's June election. Second, the high level of interest in woman suffrage not only persuaded virtually every primary voter to also vote in the referendum, but also drew to the polls

\footnotetext{
${ }^{14}$ Official Register, pp. 389-396; Des Moines Register and Leader, 3 June 1916, p. 1.

${ }^{15}$ Official Register, pp. 390, 481.

${ }^{16}$ For suggestions that fraudulent voting by the anti-suffrage forces explains the larger number of votes cast in the suffrage referendum than in the gubernatorial primary, see Harper, History Woman, 6: 189-190; and Louise
} 
considerable numbers of men who did not vote in the primary. The high level of interest in the referendum is evident in the larger number of suffrage than of gubernatorial votes statewide, and in ninety-seven of the ninety-nine lowa counties. Although the 1916 Republican primary featured contests for governor, lieutenant governor, secretary of state, attorney general, and railroad commissioner, the total referendum vote exceeded the total gubernatorial primary vote in ninety-three of the ninetyfive Republican counties, as well as in the four counties with more Democratic than Republican voters in gubernatorial balloting. ${ }^{17}$ More men participated in the referendum than in the gubernatorial primary in forty-six of the forty-eight counties which favored woman suffrage, as well as in all fifty-one of the counties which rejected the proposal. The third, and final, conclusion regarding the larger referendum vote is that opposition to woman suffrage of such traditionally Democratic groups as Roman Catholics and some German Protestants resulted in the largest referendum vote, relative to the gubernatorial vote, in the very counties where support for woman suffrage was well below the statewide level.

While religion, nationality, political party affiliation, and beliefs regarding prohibition all appear to have shaped voting behavior in the 1916 woman suffrage referendum, size of community does not appear to have been of any particular consequence. Both rural and urban voting behavior in 1916 were related to these other variables much more closely than to community size. The Pearson product-moment coefficient of correlation between the proportion of persons living on farms and

R. Noun, Strong-Minded Women: The Emergence of the Woman-Suffrage Movement in Iowa (Ames: Iowa State University Press, 1969), pp. 256-257. Noun reports that 29, 341 more votes were cast in the suffrage referendum than in the gubernatorial primary. The totals in the Official Register indicate that the difference was slightly larger-30,689.

${ }^{17}$ Only Butler and Jasper counties cast more gubernatorial than referendum votes. The four counties with more Democratic than Republican gubernatorial primary votes were Chickasaw, Davis, Dubuque, and Johnson. Considerably more voters participated in the 1916 gubernatorial primary than in any of the other primaries for state office. A total of 305,059 men voted in the gubernatorial primary, compared with 271,738 in the primary for secretary of state, the primary with the second largest number of voters. 
the pro-suffrage vote was only -.02 . This indicates that the size of the farm population can statistically explain only four onehundredths of one percent of the referendum vote.

Urban residence also evidenced little relationship to referendum voting behavior. Voters in the seven largest cities in the state supported the woman suffrage proposal at about the same levels as voters in the remainder of the counties where the cities were located. As Table 3 demonstrates, the mean pro-suffrage vote in the seven cities was only slightly above that in the less urbanized areas of the same counties, 45 percent compared with 42.2 percent. Four of the cities recorded more support for woman suffrage than the remainder of their respective counties. In the other three cities, voter approval of the proposed amendment was below the level in the outlying areas of the counties.

\section{TABLE 3}

Pro-Suffrage Vote in Seven Largest Iowa Cities and in Remainder of the Seven Counties.

\begin{tabular}{llll}
\hline \hline \multicolumn{1}{c}{ CITY } & & \multicolumn{2}{c}{ CounTY } \\
Cedar Rapids & $39.9 \%$ & Linn & $45.5 \%$ \\
Council Bluffs & $50.1 \%$ & Pottawattamie & $48.4 \%$ \\
Davenport & $33.0 \%$ & Scott & $26.0 \%$ \\
Des Moines & $54.1 \%$ & Polk & $56.8 \%$ \\
Dubuque & $32.4 \%$ & Dubuque & $19.0 \%$ \\
Sioux City & $48.6 \%$ & Woodbury & $52.2 \%$ \\
Waterloo & $57.2 \%$ & Black Hawk & $48.5 \%$ \\
\hline
\end{tabular}

SOURCE: Official Register, pp. 462-481.

If rural and urban men voted essentially alike in the 1916 referendum, within each group wide variations in voting behavior existed. Because virtually all of the ethnic townships whose voting behavior is summarized in Table 2 were farm townships, those data illustrate not only the close relationship between national origin and voting behavior, but also the wide variety in farm voting behavior in the referendum. The widely varying voting behavior of ethnic farm townships suggests 
strongly that nationality, rather than farm residence, shaped agrarian voting behavior in the 1916 referendum.

Clearly, community size has little, if any, explanatory value in connection with 1916 referendum voting behavior in lowa. On the other hand, such factors as religion, nationality, political party preference, and beliefs regarding prohibition were all associated with voting behavior to a considerable extent, and should be examined further in attempts to understand more fully the history of the woman suffrage movement in the United States. The existence of one or more suffrage referenda in a majority of the American states makes possible similar studies of this aspect of the suffrage movement among additional electorates. After completing a number of single-state studies, we will have the materials with which to make comparative studies, in an attempt to determine whether or not the same relationships between voting behavior and certain other variables existed in other states as well as in Iowa. With studies of this type we can combine the revival of interest in the history of the woman suffrage movement with the growing interest in grass-roots voting behavior, and thereby enlarge our understanding of both of these phenomena. 
Copyright of Annals of Iowa is the property of State of Iowa, by \& through the State Historical Society of Iowa and its content may not be copied or emailed to multiple sites or posted to a listserv without the copyright holder's express written permission. However, users may print, download, or email articles for individual use. 